\title{
Title: Rituximab versus cyclophosphamide as first steroid sparing agent in childhood frequently relapsing and steroid dependent nephrotic syndrome
}

Short running title: Rituximab versus cyclophosphamide in steroid-sensitive nephrotic syndrome

Authors:

*1\&2Jameela A Kari, MD, FRCP, FRCPCH: jkari@doctors.org.uk or jkari@kau.edu.sa

${ }^{*}$ Khalid A Alhasan , FRCPC: kalhasan@ksu.edu.sa

4Amr S Albanna,MD, MSc : amralbanna@gmail.com

1\&2Osama Y Safder (MD,FRCPc) :safderosama@hotmail.com

1\&2Mohamed A Shalaby (MBBS, MSC) mshalaby1977@hotmail.com

5\&6Detlef Böckenhauer(PhD): d.bockenhauer@ucl.ac.uk

1\&2Sherif M El-Desoky, MRCP, MD: sherifd68@hotmail.com

*joint first authors

Affiliations: 
${ }^{1}$ Faculty of Medicine, ${ }^{2}$ Paediatric Nephrology unit, Department of Pediatrics, King AbdulAziz University, Jeddah, Kingdom of Saudi Arabia, ${ }^{3}$ Pediatrics Department, King Saud University, Riyadh, Kingdom of Saudi Arabia , ${ }^{4}$ King Abdullah International Medical Research Center, King Saud Bin Abdul-Aziz University for Health Sciences, Jeddah, Kingdom of Saudi Arabia, ${ }^{5}$ Department of Renal Medicine, University College London, London, UK

${ }^{6}$ Renal Unit, Great Ormond Street Hospital for Children NHS Foundation Trust, London, UK

Number of tables: 2

Number of figures: 4

Number of words: 2322

Number of references; 29

Number of authors: 7

Conflict of interest: None

Disclose: The work is original and not presented before

\section{Corresponding Author:}

Name: Jameela Abdulaziz Kari 
Address: King Abdul-Aziz University, PO Box 80215, Jeddah 21589, Kingdom of Saudi Arabia

Phone number: +996 505677904

E-mail address: jkari@doctors.org.uk or jkari@kau.edu.sa 


\section{Abstract:}

Background: Approximately $50 \%$ of children with steroid sensitive nephrotic syndrome (SSNS) will suffer from frequent relapses or steroid dependency, prompting the use of so-called steroid-sparing drugs. In this pilot study, we compare the efficacy and safety of rituximab to oral cyclophosphamide as first-line steroid-sparing medications.

Methods: A prospective open label non-randomized study of children with frequent relapsing or steroid-dependant SSNS. Exclusion criteria were steroid-resistant disease, prescription of immunosuppressive agents other than prednisolone or levamisole, evidence of impaired kidney function, leucopenia or active infection. The recruited children were allocated either to the oral cyclophosphamide $(3 \mathrm{mg} / \mathrm{kg} /$ day for 8 weeks) or intravenous rituximab treatment (two doses of $375 \mathrm{mg} / \mathrm{m}^{2} / \mathrm{dose}$, 2 weeks apart) and were monitored for relapses and side effects for 12 months.

Results: 46 subjects were included from two centers; 27 received cyclophosphamide and 19 received rituximab. One-year relapse-free survival was reached in 17 (58.6\%) patients treated with cyclophosphamide compared to 16 (84.2\%) with rituximab (adjusted HR: $0.36 ; 95 \% \mathrm{Cl}: 0.09-1.45 ; p=0.151)$. The mean interval to relapse was 6.9 months in the cyclophosphamide group $(\mathrm{N}=10)$ and 6.3 months in the rituximab group $(\mathrm{N}=3)$. Both treatments were associated with a significant $(p<0.001)$ reduction in prescribed dose of oral alternate days steroid from 1.02 to $0.36 \mathrm{mg} / \mathrm{kg}$ (cyclophosphamide) and 0.86 to $0.08 \mathrm{mg} / \mathrm{kg}$ (rituximab). Importantly, a significantly $(\mathrm{p}=0.003)$ higher percentage of patients achieved complete withdrawal of steroid within 3 months of commencing study treatment in the rituximab (73.7\%) versus cyclophosphamide (29.6\%) group. 
Transient leucopenia was the most frequent adverse effect observed in the cyclophosphamide group (18.5\%) and one patient (3.4\%) had acute hepatotoxicity beside severe leucopenia and neutropenia in the $7^{\text {th }}$ week of treatment with complete recovery with withdrawal of cyclophosphamide and maintenance of remission. A minor infusion related reaction in form of a generalized macular skin rash was observed in 1 patient (5\%) in the rituximab group.

Conclusion: Rituximab is non-inferior to cyclophosphamide and safe as a first-line steroidsparing agent in children with SSNS. A larger multicenter study is required to assess superiority over cyclophosphamide. 


\section{Introduction:}

Childhood idiopathic nephrotic syndrome (INS) is sensitive to steroid therapy in most children and therefore often referred to as steroid-sensitive nephrotic syndrome (SSNS). However, a significant number (40-50\%) of patients will have frequent relapses (FRNS) or steroid-dependent disease (SDNS) [1].

Various steroid-sparing immunosuppressive medications have been used to maintain remission in these children; however, these medications have significant potential adverse effects. There is no consensus on the most appropriate first-line sparing agent in children with relapsing steroid-sensitive disease [2].

Oral cyclophosphamide (OCP) has been used as a steroid-sparing therapy for children with FRNS or SDNS. The average response rate (remission for one year or longer) in various studies has ranged from 28 to $75 \%$ for SDNS children and from 24 to $70 \%$ in FRNS at 1-3 years [3]. The wide availability, affordability and efficacy of cyclophosphamide, with induction of long-term remission ( $\geq$ a year) in approximately a third of patients have promoted its use as a steroid sparing agent in childhood SSNS [4]. However, this must be balanced against potential side effects of alkylating agents such as leucopenia, bladder toxicity and risk of infertility [5].

Rituximab was first reported in the treatment of nephrotic syndrome in 2004 [6]. Since then, numerous case reports and case series have been published supporting the efficacy of rituximab in the treatment of nephrotic syndrome. In the difficult group of steroiddependent or resistant cases, the use of rituximab has been associated with partial or complete remission rates of $77-91 \%$ and many patients were able to discontinue other immunosuppressive medications [7]. Traditionally, rituximab has been used as a "drug of 
last resort" in patients with difficult to treat SSNS, who had exhausted all other immunosuppressive treatments and comparison with other drugs is mainly limited to retrospective cohort studies [2,8]. Late-onset neutropenia occurring at least 4 weeks after treatment has been reported following rituximab treatment for hematologic disorders [9]. B-cell recovery usually occurs within approximately 6 months following the completion of treatment [10], but this is not directly associated with relapse [11]. Rituximab is usually well tolerated with only rare occurrences of serious adverse events, making it an attractive therapeutic option in patients with autoimmune or immune-mediated conditions [12].

Based on the favourable experience, rituximab has been proposed as a potential replacement for cyclophosphamide and calcineurin inhibitors in SDNS [13]. Here we report on a prospective clinical trial to better assess rituximab versus cyclophosphamide as a first-line steroid sparing medication in children with FRNS and SDNS. 


\section{Patient and Methods:}

We performed a prospective, open-label, non-randomised pilot study of pediatric patients ( $>1$ and $<18$ years) diagnosed with idiopathic frequently relapsing (defined as two or more relapses within 6 months after the initial response, or four or more relapses over a12month duration) and/or steroid dependent (defined as two consecutive relapses while tapering corticosteroid therapy, or within 14 days of stopping steroid) nephrotic syndrome, who received only steroid treatment with or without levamisole. To minimise the costs of the study, it was performed within the routine clinical care of the patients. Adjustment of steroid dose was at the discretion of the treating physician. All patients/legal guardians provided written and informed consent.

The research ethics committees at both contributing centers approved the study. Written informed consents were obtained from one of the parents of all included children. The study was performed according to the principles of the declaration of Helsinki.

Inclusion criteria included normal estimated glomerular filtration rate $(\mathrm{eGFR}=>90 \mathrm{ml} / \mathrm{min}$ per $1.73 \mathrm{~m}^{2}$ ), remission at study entry with nil or trace proteinuria by dipstick test or urine protein $<100 \mathrm{mg} / \mathrm{dl}$ for at least 3 days. Exclusion criteria included the following: current or previous prescription of other immunosuppressive agents, steroid-resistant nephrotic syndrome (SRNS) and secondary forms of nephrotic syndrome; congenital and infantile onset nephrotic syndrome, severe leucopenia (leucocytes $<3.0 \times 1000$ cells $/ \mathrm{mm}^{3}$ ), neutropenia (neutrophil count $<1500$ ) or evidence of active infection defined by either fever $\geq 38$ Celsius, high leucocyte count, high C-reactive protein or positive blood or urine culture results. 
Eligible children were allocated either to cyclophosphamide using $3 \mathrm{mg} / \mathrm{kg} / \mathrm{day}$ for 8 weeks or rituximab with two doses of $375 \mathrm{mg} / \mathrm{m}^{2}$ intravenous infusion two weeks apart. Both treatments were offered to parents and they selected between them. Premedication in the form of methylprednisolone $100 \mathrm{mg}$ in $100 \mathrm{ml}$ normal saline infused over 30 minutes, intravenous chlorphenamine $10 \mathrm{mg}$ and paracetamol $10 \mathrm{mg} / \mathrm{kg}$ orally was commenced 60 minutes before rituximab infusion. The following investigations were performed for both groups at 3, 6 and 12 months: complete blood count (CBC), differential count, renal and, liver function test, urine analysis, albumin/creatinine ratio. For cyclophosphamide group; weekly $\mathrm{CBC}$, differential count was performed during the treatment course. Children were reviewed monthly in the outpatient clinic during the study duration and adjustment of the prednisolone dose was at the discretion of the treating physician. Glomerular filtration rate was estimated (eGFR) using the revised Schwartz formula at the beginning and at the end of the study [14].

Children were followed for a minimum of 12 months. Complete remission was defined as negative or trace proteinuria (albustix) for 3 consecutive early morning urine specimens or a urine albumin/creatinine ratio $<30 \mathrm{mg} / \mathrm{g}$ and serum albumin $>35 \mathrm{gm} / \mathrm{l}$. Partial remission was defined as proteinuria level reduced by $50 \%$ and/or urine albumin/creatinine $>30 \mathrm{mg} / \mathrm{g}$ and $<300 \mathrm{mg} / \mathrm{g}$ and/or serum albumin $>25 \mathrm{~g} / \mathrm{l}$ but $<35 \mathrm{~g} / \mathrm{l}$. Relapse was defined as nephrotic range proteinuria as assessed by $\geq 2+$ on urine albustix for 3 consecutive days and/or protein/creatinine ratio $>2.0 \mathrm{mg} / \mathrm{g}$ and $/$ or albumin/creatinine $>300 \mathrm{mg} / \mathrm{g}$ and/or urine protein $1 \mathrm{~g} / \mathrm{m}^{2} /$ day in 24 hours urine collection and serum albumin $<25 \mathrm{~g} / \mathrm{l}$. SSNS was defined as achieving remission within 4 weeks of full dose prednisolone. Steroid resistant nephrotic syndrome (SRNS) was defined as not achieving 
remission after 4 weeks on daily dose of oral prednisolone $\left(60 \mathrm{mg} / \mathrm{m}^{2}\right)(15)$. The primary study end point was occurrence of relapse or significant drug adverse effects during the study observation period. Secondary study end point was maintenance of remission for 12 months after completion of the study treatment course with no other therapy or with a small dose $(\leq 0.5 \mathrm{mg} / \mathrm{kg} /$ alternate days $)$ of alternate oral steroids.

Other outcome measures were: cessation of oral prednisolone within the first 3 month after completion of the treatment course in patients who maintained remission or the dose of alternate day oral prednisolone to maintain remission.

The initial power analysis suggested a sample size of 165 subjects per treatment arm (total of 330 subjects), based on an estimated relapse rate of $40 \%$ with the standard treatment (cyclophosphamide), clinically important effect size of $15 \%$, power of $80 \%$ and alpha of 0.05 . In order to get more accurate estimates on relapse rate and effect size in our patient population, this pilot study was set up to provide more accurate data for a power analysis for designing a definitive clinical trial.

Statistical analysis: All analyses were performed using STATA (StataCorp. 2011. Stata Statistical Software: Release 12. College Station, TX: StataCorp LP) software. The proportion and mean for dichotomous and continuous variables, respectively, were measured to describe patients' characteristics. The relapse-free survival among patients treated with rituximab and cyclophosphamide was analysed using the Kaplan-Meier Curve. Comparison of the relapse-free survival between both treatment groups was estimated using the Cox proportional-hazards regression model. A multi-variable regression model was used to adjust for the following potential confounding variables: age, sex, and number of disease relapses during the year prior to treatment. The effect 
of using rituximab and cyclophosphamide on reducing the steroid dose was estimated using paired $t$ test (comparing the lower required steroid dose during a year of follow-up before and a year after the start of treatment). Comparison of the adverse-drug reactions between the two treatment groups was estimated using chi-square test. Statistical significance was determined using the $95 \%$ confidence interval and $p$-value of 0.05 . 


\section{Results:}

Forty-six children were included from two centers from the Kingdom of Saudi Arabia; 27 were allocated to cyclophosphamide and 19 to rituximab. The baseline patients' characteristics are shown in table 1.

The one-year relapse-free survival was reached in 17 (58.6\%) patients treated with cyclophosphamide compared to 16 (84.2\%) with rituximab (adjusted HR: 0.36 ; $95 \% \mathrm{Cl}$ : $0.09-1.45 ; p=0.151)$ (figure.1). Eight patients $(29.6 \%)$ in the cyclophosphamide group and $14(73.7 \%)$ in the rituximab group achieved complete withdrawal of oral prednisolone within 3 months of treatment $(\mathrm{p}=0.003)$ (figure 2$)$. Furthermore, both oral cyclophosphamide and intravenous rituximab were associated with a significant reduction in the prescribed dose of oral alternate day steroid during the year of follow-up from 1.02 to $0.36 \mathrm{mg} / \mathrm{kg}$ (cyclophosphamide) and 0.86 to $0.08 \mathrm{mg} / \mathrm{kg}$ (rituximab, figure 3 ). In those patients who relapsed in the first year, the mean interval to relapse was comparable at 6.9 months in the cyclophosphamide group $(\mathrm{N}=10)$ and 6.3 months in the rituximab group $(\mathrm{N}=3)$. Table 2 shows the changes of laboratory investigations over the follow-up period among both groups.

Transient leucopenia was the most frequent adverse effect observed in the cyclophosphamide group (22\%) and one patient girl (3.5\%) had acute hepatotoxicity (elevations of liver enzymes), beside severe leucopenia and neutropenia on the $7^{\text {th }}$ week of treatment. She showed complete recovery within few days of discontinuation of cyclophosphamide and remained in remission. A minor infusion related reaction was observed in 1 patient $(5.2 \%)$ of rituximab group (figure 4 ). 


\section{Discussion}

Our study showed that both rituximab and cyclophosphamide were associated with a significant reduction of the dose of steroid prescribed in children with FRNS or SDNS. Importantly, the proportion of patients stopping prednisolone after three months of therapy was significantly higher with rituximab. While adjustment of the dose of prednisolone was at the discretion of the treating physician, the fact that the proportion of patients achieving one-year relapse-free survival was higher with rituximab, albeit not statistically significant, argues against a biased adjustment of the dose. Our data thus fit with evidence from recently published studies, supporting a beneficial effect of rituximab in the treatment of FRNS or SDNS with the advantage of minimizing the use of steroids and other immunosuppressive drugs [16-19].

Webb et al, in a retrospective study comparing rituximab to cyclophosphamide, showed that most children could be weaned off prednisolone while maintaining remission after rituximab therapy: the median time off prednisolone was 12 months for children treated with rituximab versus three months for those who received cyclophosphamide, while the median time to relapse was 7 months following cyclophosphamide treatment and 14 months following rituximab. Long-term remission (>24 months) was assessed as patients in their study had at least 2 years of follow-up after treatment and was achieved in $24 \%$ after cyclophosphamide and $32 \%$ after rituximab [16]. Of note, only the most difficult to treat patients who were deemed inadequately controlled on other immunosuppressants were prescribed rituximab in this study, therefore potentially biasing the results against rituximab. 
Ravani et al, compared using rituximab with calcineurin inhibitors (CNI) in children with SDNS on prednisolone. They reported the risk of relapse was lower in the rituximab group, while the probabilities of being off prednisone at 3 months was higher in the rituximab group [19]. Gulati et al, showed that two doses of rituximab treatment induced sustained remission in 20 of $24(83.3 \%)$ patients with complicated SDNS [20]. A multicenter, double-blind, randomized, placebo-controlled trial from Japan showed that weekly doses for 4 weeks induced significantly longer remission in the rituximab group than in the placebo group with significantly lower daily steroid dose after randomization in the rituximab group than in the placebo group [21].

Our data show that children who received rituximab appeared to have fewer adverse drug reactions than those who received cyclophosphamide. This is line with other studies who found that rituximab was associated with a low rate of adverse effects [16, 22].

However, there are case reports of serious complications following rituximab administration, including progressive multifocal encephalopathy and progressive pulmonary fibrosis [23]. It is important to note that these cases received multiple immunosuppressive drugs and the serious complications may thus not only be attributable to rituximab but to the compound effect of the various drugs.

There was no mortality in our study and the adverse effects in either group were infrequent and mild. With cyclophosphamide, transient and reversible leucopenia with neutropenia were the commonest, only one case had also acute hepatitis. Hepatotoxicity with high-dose cyclophosphamide is well recognized, but hepatitis due to low-dose cyclophosphamide immediately after treatment has rarely been described [24]. 
Hepatotoxicity may occur even after low-dose intravenous cyclophosphamide treatment [25], as well as oral cyclophosphamide [26]. Initial and follow-up liver function tests should be monitored in all patients receiving cyclophosphamide treatment.

Other reported acute adverse effects of cyclophosphamide treatment include bone marrow suppression with opportunistic infections, hemorrhagic cystitis, temporary infertility, nausea, vomiting, and hair loss. Pneumonitis, liver or cardiac toxicity is rarely reported. In addition, cyclophosphamide (especially with increased cumulative dose) is associated with an increased incidence of myelodysplastic syndrome, lymphoma, bladder carcinoma, and permanent infertility after several years of treatment [27]. This obviously limits the repeated administration of cyclophosphamide. In contrast, rituximab has been given repeatedly, especially in rheumatoid disease, albeit complicated by hypogammaglubinaemia in some cases [28].

The only adverse event observed with rituximab in our study was a mild infusion reaction with generalized macular skin rash, which occurred in one case and resolved after decreasing the rate of infusion. Similarly, Takei et al, reported only infusion reactions, such as rash and chills, after single-dose rituximab infusion which can be managed by pre-medication or infusion rate adjustments [29].

Several potential limitations of this study merit consideration. One of the main limitations is the small sample size, which makes it difficult to draw relevant comparisons. The second limitation is the relatively short follow-up of the patients, which may mask a potential longer-term effect of rituximab. Nevertheless, our results so far exceed our expectations prior to the start of the study and a repeat power analysis based on a relapse free rate of $58.6 \%$ with cyclophosphamide, versus $84.2 \%$ with rituximab treatment, 
suggest that a much smaller sample size of 112 subjects will be needed for a meaningful study, compared to the initially calculated 330 subjects per treatment arm.

Conclusions from our study are limited by the lack of a general consensus on rituximab dose and number of infusions per treatment cycle. In this study, we applied a protocol of two infusions of rituximab of $375 \mathrm{mg} / \mathrm{m}^{2}$ each. Previous trials have used between $1-4$ infusions per cycle and the total dose per cycle varies from 375 to $1875 \mathrm{mg} / \mathrm{m}^{2}$ between treatment protocols [30-36]. In a recent retrospective analysis of 511 children with FRNS/SDNS treated at 11 tertiary centers, the medium dose of $750 \mathrm{mg} / \mathrm{m}^{2}$ was the most commonly used regime and associated with longer remission time compared to 375 $\mathrm{mg} / \mathrm{m}^{2}$ [37]. Thus, our results reflect the most commonly used treatment protocol and consequently, our results inform the treatment at most centres.

Lastly, albuminuria at baseline was not comparable, being significantly higher in the cyclophosphamide group (table 2). Likely, this reflects the aim of clinicians to achieve complete remission before administration of rituximab to avoid potential loss of the drug in the urine. If so, it suggests that prednisolone use may have been higher in the rituximab group before study entry, potentially introducing a bias. As data on prednisolone dosage were not captured, except for the lowest dose during the study, such a bias cannot be excluded.

\section{Conclusion}

Our pilot data suggest that rituximab is effective and safe as a first-line sparing agent in children with steroid-dependent or frequently relapsing nephrotic syndrome. However, a 
larger multicenter study is required to confirm the superiority of rituximab over cyclophosphamide in its ability to prolong the relapse-free survival and minimize or eliminate the need for steroids in children with frequently relapsing or steroid-dependent nephrotic syndrome.

\section{Acknowledgement}

This Project was funded by the Deanship of Scientific Research (DSR), at King Abdulaziz University, Jeddah, under grant no. G:33-140-1441. The authors, therefore, acknowledge with thanks DSR for technical and financial support 
Tables:

Table 1: Baseline Patients' demographic and disease characteristics, showing no difference between children received cyclophosphamide and those who received rituximab.

Table 2: Results of laboratory investigation among patients treated with rituximab versus cyclophosphamide at baseline and during one-year follow up. Both groups had normal kidney function over the study duration.

Figures:

Figure 1: Relapse-free survival during one-year follow-up comparing patients treated with rituximab and cyclophosphamide. The one-year relapse-free survival was $58.6 \%$ with cyclophosphamide compared to $84.2 \%$ with rituximab (adjusted HR: 0.36; $95 \% \mathrm{Cl}: 0.09$ $-1.45 ; p=0.151)$

Figure 2: Steroid withdrawal within three months of treatment achieved in (73.7\%) with rituximab compared to (29.6\%) with cyclophosphamide $(p=0.003)$

Figure 3: The effect on reducing the prescribed dose of oral alternate day steroid during the year of follow-up was from 1.02 to $0.36 \mathrm{mg} / \mathrm{kg}$ (cyclophosphamide) and 0.86 to $0.08 \mathrm{mg} / \mathrm{kg}$ (rituximab)

Figure 4: Adverse drug reactions associated with the use of rituximab (5\%= infusion related reaction) compared to cyclophosphamide ( $22 \%$ leucopenia $+3.5 \%$ hepatotoxicity). 
References:

1. Vivarelli M, Massella L, Ruggiero B, Emma F (2017), Minimal Change Disease, Clin.J.Am.Soc.Nephrol. 12: 332-345

2. Pravitsitthikul N, Willis NS, Hodson EM, Craig JC (2013), Non-corticosteroid immunosuppressive medications for steroid-sensitive nephrotic syndrome in children, Cochrane.Database.Syst.Rev. CD002290

3. Garin EH, Pryor ND, Fennell RS, III, Richard GA (1978), Pattern of response to prednisone in idiopathic, minimal lesion nephrotic syndrome as a criterion in selecting patients for cyclophosphamide therapy, J Pediatr. 92: 304-308

4. Fu HD, Qian GL, Jiang ZY (2017), Comparison of second-line immunosuppressants for childhood refractory nephrotic syndrome: a systematic review and network metaanalysis, J Investig.Med. 65: 65-71

5. Kyrieleis HA, Lowik MM, Pronk I, Cruysberg HR, Kremer JA, Oyen WJ, van den Heuvel BL, Wetzels JF, Levtchenko EN (2009), Long-term outcome of biopsyproven, frequently relapsing minimal-change nephrotic syndrome in children, Clin.J Am Soc.Nephrol. 4: 1593-1600

6. Benz K, Dotsch J, Rascher W, Stachel D (2004), Change of the course of steroiddependent nephrotic syndrome after rituximab therapy, Pediatr.Nephrol. 19: 794797 
7. Sun L, Xu H, Shen Q, Cao Q, Rao J, Liu HM, Fang XY, Zhou LJ (2014), Efficacy of rituximab therapy in children with refractory nephrotic syndrome: a prospective observational study in Shanghai, World J.Pediatr. 10: 59-63

8. Wang $X, X u H$ (2013), New insights into treatment of nephrotic syndrome in children, Contrib.Nephrol. 181: 119-130

9. Chaiwatanatorn K, Lee N, Grigg A, Filshie R, Firkin F (2003), Delayed-onset neutropenia associated with rituximab therapy, Br.J Haematol. 121: 913-918

10. Dunleavy K, Hakim F, Kim HK, Janik JE, Grant N, Nakayama T, White T, Wright G, Kwak L, Gress R, Tosato G, Wilson WH (2005), B-cell recovery following rituximabbased therapy is associated with perturbations in stromal derived factor- 1 and granulocyte homeostasis, Blood 106: 795-802

11. Colucci M, Carsetti R, Cascioli S, Casiraghi F, Perna A, Rava L, Ruggiero B, Emma F, Vivarelli M (2016), B Cell Reconstitution after Rituximab Treatment in Idiopathic Nephrotic Syndrome, J Am Soc.Nephrol. 27: 1811-1822

12. Kattah AG, Fervenza FC, Roccatello D (2013), Rituximab-based novel strategies for the treatment of immune-mediated glomerular diseases, Autoimmun.Rev. 12: 854859

13. Dotsch J, Muller-Wiefel DE, Kemper MJ (2008), Rituximab: is replacement of cyclophosphamide and calcineurin inhibitors in steroid-dependent nephrotic syndrome possible?, Pediatr.Nephrol. 23: 3-7 
14. Schwartz GJ, Brion LP, Spitzer A (1987), The use of plasma creatinine concentration for estimating glomerular filtration rate in infants, children, and adolescents, Pediatr.Clin.North Am 34: 571-590

15. Sinha A, Bagga A (2012), Nephrotic syndrome, Indian J Pediatr. 79: 1045-1055

16. Webb H, Jaureguiberry G, Dufek S, Tullus K, Bockenhauer D (2016), Cyclophosphamide and rituximab in frequently relapsing/steroid-dependent nephrotic syndrome, Pediatr.Nephrol. 31: 589-594

17. Hogan J, Deschenes G (2019), How to improve response to rituximab treatment in children with steroid-dependent nephrotic syndrome: answer to Drs. Fujinaga and Nishino, Pediatr.Nephrol. 34: 361-362

18. Ravani P, Ponticelli A, Siciliano C, Fornoni A, Magnasco A, Sica F, Bodria M, Caridi G, Wei C, Belingheri M, Ghio L, Merscher-Gomez S, Edefonti A, Pasini A, Montini G, Murtas C, Wang X, Muruve D, Vaglio A, Martorana D, Pani A, Scolari F, Reiser J, Ghiggeri GM (2013), Rituximab is a safe and effective long-term treatment for children with steroid and calcineurin inhibitor-dependent idiopathic nephrotic syndrome, Kidney Int. 84: 1025-1033

19. Ravani P, Magnasco A, Edefonti A, Murer L, Rossi R, Ghio L, Benetti E, Scozzola F, Pasini A, Dallera N, Sica F, Belingheri M, Scolari F, Ghiggeri GM (2011), Shortterm effects of rituximab in children with steroid- and calcineurin-dependent nephrotic syndrome: a randomized controlled trial, Clin.J Am Soc.Nephrol. 6: 13081315 
20. Gulati A, Sinha A, Jordan SC, Hari P, Dinda AK, Sharma S, Srivastava RN, Moudgil A, Bagga A (2010), Efficacy and safety of treatment with rituximab for difficult steroidresistant and -dependent nephrotic syndrome: multicentric report, Clin.J Am Soc.Nephrol. 5: 2207-2212

21. lijima K, Sako M, Nozu K, Mori R, Tuchida N, Kamei K, Miura K, Aya K, Nakanishi K, Ohtomo Y, Takahashi S, Tanaka R, Kaito H, Nakamura H, Ishikura K, Ito S, Ohashi Y (2014), Rituximab for childhood-onset, complicated, frequently relapsing nephrotic syndrome or steroid-dependent nephrotic syndrome: a multicentre, double-blind, randomised, placebo-controlled trial, Lancet 384: 1273-1281

22. Bonanni A, Calatroni M, D'Alessandro M, Signa S, Bertelli E, Cioni M, Di Marco E, Biassoni R, Caridi G, Ingrasciotta G, Bertelli R, Di Donato A, Bruschi M, Canepa A, Piaggio G, Ravani P, Ghiggeri GM (2018), Adverse events linked with the use of chimeric and humanized anti-CD20 antibodies in children with idiopathic nephrotic syndrome, British journal of clinical pharmacology 2018/03/25: 1238-1249

23. Berger JR, Malik V, Lacey S, Brunetta P, Lehane PB (2018), Progressive multifocal leukoencephalopathy in rituximab-treated rheumatic diseases: a rare event, Journal of neurovirology 2018/03/05: 323-331

24. Cleland BD, Pokorny CS (1993), Cyclophosphamide related hepatotoxicity, Aust.N.Z.J Med. 23: 408

25. Subramaniam SR, Cader RA, Mohd R, Yen KW, Ghafor HA (2013), Low-dose cyclophosphamide-induced acute hepatotoxicity, Am J Case.Rep. 14: 345-349 
26. Snyder LS, Heigh RI, Anderson ML (1993), Cyclophosphamide-induced hepatotoxicity in a patient with Wegener's granulomatosis, Mayo Clin.Proc. 68: $1203-1204$

27. M.Haubitz.Acute and Long-term Toxicity of Cyclophosphamide. Transplantationsmedizin. 2007;S 26-S 31.

28. Roberts DM, Jones RB, Smith RM, Alberici F, Kumaratne DS, Burns S, Jayne DRW (2015), Rituximab-associated hypogammaglobulinemia: incidence, predictors and outcomes in patients with multi-system autoimmune disease, Journal of autoimmunity 2014/12/31: 60-65

29. Takei T, Nitta K (2011), Rituximab and minimal change nephrotic syndrome: a therapeutic option, Clin.Exp.Nephrol. 15: 641-647

30. Prytu!,a A, lijima K, Kamei K, Geary D, Gottlich E, Majeed A, Taylor M, Marks SD, Tuchman S, Camilla R, Ognjanovic M, Filler G, Smith G, Tullus K (2010), Rituximab in refractory nephrotic syndrome, Pediatric nephrology (Berlin, Germany) 2009/12/23: 461-468

31. Ahn YH, Kim SH, Han KH, Choi HJ, Cho H, Lee JW, Shin JI, Cho MH, Lee JH, Park YS, Ha IS, Cheong HI, Kim SY, Lee SJ, Kang HG (2018), Efficacy and safety of rituximab in childhood-onset, difficult-to-treat nephrotic syndrome: A multicenter open-label trial in Korea, Medicine 97: e13157

32. Ruggenenti $P$, Ruggiero B, Cravedi P, Vivarelli M, Massella L, Marasi M, Chianca A, Rubis N, Ene-lordache B, Rudnicki M, Pollastro RM, Capasso G, Pisani A, 
Pennesi M, Emma F, Remuzzi G, Rituximab in Nephrotic Syndrome of SteroidDependent or Frequently Relapsing Minimal Change Disease Or Focal Segmental Glomerulosclerosis (NEMO) Study Group (2014), Rituximab in steroid-dependent or frequently relapsing idiopathic nephrotic syndrome, Journal of the American Society of Nephrology : JASN 2014/01/30: 850-863

33. Nakagawa T, Shiratori A, Kawaba Y, Kanda K, Tanaka R (2016), Efficacy of rituximab therapy against intractable steroid-resistant nephrotic syndrome, Pediatrics international: official journal of the Japan Pediatric Society 2016/06/23: 1003-1008

34. Ravani P, Rossi R, Bonanni A, Quinn RR, Sica F, Bodria M, Pasini A, Montini G, Edefonti A, Belingheri M, De Giovanni D, Barbano G, Degl'Innocenti L, Scolari F, Murer L, Reiser J, Fornoni A, Ghiggeri GM (2015), Rituximab in Children with Steroid-Dependent Nephrotic Syndrome: A Multicenter, Open-Label, Noninferiority, Randomized Controlled Trial, Journal of the American Society of Nephrology : JASN 2015/01/15: 2259-2266

35. Kamei K, Ito S, Nozu K, Fujinaga S, Nakayama M, Sako M, Saito M, Yoneko M, lijima K (2009), Single dose of rituximab for refractory steroid-dependent nephrotic syndrome in children, Pediatric nephrology (Berlin, Germany) 2009/05/07: 13211328

36. Scolari F, Dallera N, Gesualdo L, Santoro D, Pani A, Santostefano M, Feriozzi S, Mani LY, Boscutti G, Messa P, Magistroni R, Quaglia M, Ponticelli C, Ravani P (2019), Rituximab versus steroids and cyclophosphamide for the treatment of 
primary membranous nephropathy: protocol of a pilot randomised controlled trial, BMJ Open 9: e029232

37. Chan EY-H, Webb H, Yu E, Ghiggeri GM, Kemper MJ, Ma AL-T, Yamamura T, Sinha A, Bagga A, Hogan J, Dossier C, Vivarelli M, Liu ID, Kamei K, Ishikura K, Saini P, Tullus K (2020), Both the rituximab dose and maintenance immunosuppression in steroid-dependent/frequently-relapsing nephrotic syndrome have important effects on outcomes, Kidney international 2019/10/31: 393-401

Table 1: Baseline Patients' demographic and disease characteristics.

\begin{tabular}{lllll}
\hline \multirow{2}{*}{ Characteristics } & \multicolumn{2}{c}{ Rituximab } & \multicolumn{2}{c}{ Cyclophosphamide } \\
\cline { 2 - 5 } & Estimate & $95 \%$ CI & Estimate & $95 \%$ CI \\
\hline Age (mean, months) & 86.2 & $66.7-105.6$ & 68.2 & $55.1-81.2$ \\
\hline Male sex (\%) & 73.7 & $48.8-90.9$ & 48.1 & $28.7-68.1$ \\
\hline Baseline weight & & & & \\
Mean (kg) & 27.9 & $22.8-33.0$ & 27.3 & $21.8-32.8$ \\
Z-score & 1.22 & $0.59-1.8$ & 1.33 & $0.56-2.10$ \\
Percentile & 78.2 & $65.2-91.2$ & 73.1 & $61.1-85.2$ \\
\hline Baseline height & & & & 111 \\
Mean (cm) & 114 & $107-120$ & 117
\end{tabular}




\begin{tabular}{|c|c|c|c|c|}
\hline Z-score & -0.41 & $-0.92-0.98$ & -0.03 & $-0.99-0.94$ \\
\hline Percentile & 41.2 & $28.2-54.2$ & 40.9 & $27.7-54.0$ \\
\hline \multicolumn{5}{|l|}{ Baseline BMI } \\
\hline Mean & 21.1 & $18.6-23.5$ & 21.0 & $18.5-23.5$ \\
\hline Z-score & 1.75 & $1.10-2.44$ & 1.5 & $0.92-2.1$ \\
\hline Percentile & 85.8 & $73.0-98.5$ & 78.6 & $66.9-90.2$ \\
\hline \multicolumn{5}{|l|}{ Baseline BP (systolic BP/diastolic BP) } \\
\hline Mean (mmHg) & $111 / 64$ & $105 / 59-116 / 70$ & $112 / 68$ & $109 / 64-115 / 72$ \\
\hline \multirow[t]{2}{*}{ Z-score } & \multirow[b]{2}{*}{$1.4 / 0.87$} & $0.93 / 0.44$ & \multirow[b]{2}{*}{$1.4 / 1.0$} & \multirow[b]{2}{*}{$0.97 / 0.4-1.9 / 1.6$} \\
\hline & & $1.9 / 1.3$ & & \\
\hline Percentile & $84 / 74$ & $74 / 63-94 / 85$ & $88 / 78$ & $80 / 69-95 / 88$ \\
\hline Use of ACEI (\%) & 47.4 & $24.4-71.1$ & 74.1 & $53.7-88.9$ \\
\hline Disease relapse in the past year (\%) & 94.7 & $74.0-99.9$ & 100 & $87.2-100$ \\
\hline
\end{tabular}

Abbreviations: BMI, body mass index; BP, blood pressure; 
Table 2: Results of laboratory investigation among patients treated with rituximab versus cyclophosphamide at baseline and during one-year follow up.

\begin{tabular}{|c|c|c|c|c|c|c|c|c|c|}
\hline Laboratory test & Treatment regimen & Baseline & P Value & 3 months & P Value & 6 months & P Value & 12 months & P Value \\
\hline WBC (k/ul) & $\begin{array}{l}\text { Rituximab } \\
\text { Cyclophosphamide }\end{array}$ & $\begin{array}{l}14.4 \\
11.1\end{array}$ & 0.0696 & $\begin{array}{l}10.6 \\
8.2\end{array}$ & 0.0624 & $\begin{array}{l}10.0 \\
9.4\end{array}$ & 0.4075 & $\begin{array}{l}9.8 \\
10.2\end{array}$ & 0.7065 \\
\hline $\begin{array}{l}\text { Neutrophils PNL } \\
\text { (k/ul) }\end{array}$ & $\begin{array}{l}\text { Rituximab } \\
\text { Cyclophosphamide }\end{array}$ & $\begin{array}{l}7.39 \\
6.28\end{array}$ & 0.3668 & $\begin{array}{l}5.19 \\
5.13\end{array}$ & 0.9515 & $\begin{array}{l}5.18 \\
5.29\end{array}$ & 0.8471 & $\begin{array}{l}4.92 \\
6.24\end{array}$ & 0.0838 \\
\hline $\begin{array}{l}\text { Creatinine } \\
\text { (umol/l) }\end{array}$ & $\begin{array}{l}\text { Rituximab } \\
\text { Cyclophosphamide }\end{array}$ & $\begin{array}{l}28.6 \\
31.6\end{array}$ & 0.2857 & $\begin{array}{l}29.1 \\
30.9\end{array}$ & 0.4938 & $\begin{array}{l}30.6 \\
34.4\end{array}$ & 0.2005 & $\begin{array}{l}33.5 \\
33.2\end{array}$ & 0.9206 \\
\hline $\begin{array}{l}\text { eGFR } \\
\left(\mathrm{mL} / \mathrm{min} / \mathrm{m}^{2}\right)\end{array}$ & $\begin{array}{l}\text { Rituximab } \\
\text { Cyclophosphamide }\end{array}$ & $\begin{array}{l}129.0 \\
125.4\end{array}$ & 0.6602 & - & - & - & - & $\begin{array}{l}125.3 \\
128.7\end{array}$ & 0.6334 \\
\hline $\begin{array}{ll}\text { Blood } & \text { urea } \\
(\mathrm{mmol} / \mathrm{l}) & \end{array}$ & $\begin{array}{l}\text { Rituximab } \\
\text { Cyclophosphamide }\end{array}$ & $\begin{array}{l}3.64 \\
3.73\end{array}$ & 0.8199 & $\begin{array}{l}3.28 \\
3.23\end{array}$ & 0.8323 & $\begin{array}{l}3.88 \\
4.4\end{array}$ & 0.4763 & $\begin{array}{l}3.88 \\
3.52\end{array}$ & 0.2370 \\
\hline $\operatorname{ALT}(\mathrm{U} / \mathrm{l})$ & $\begin{array}{l}\text { Rituximab } \\
\text { Cyclophosphamide }\end{array}$ & $\begin{array}{l}24.2 \\
28.2\end{array}$ & 0.1246 & $\begin{array}{l}26.5 \\
66.7\end{array}$ & 0.3679 & $\begin{array}{l}27.3 \\
31.8\end{array}$ & 0.1884 & $\begin{array}{l}28.2 \\
32\end{array}$ & 0.3034 \\
\hline Albumin (g/l) & $\begin{array}{l}\text { Rituximab } \\
\text { Cyclophosphamide }\end{array}$ & $\begin{array}{l}32.4 \\
32.7\end{array}$ & 0.0077 & $\begin{array}{l}38.1 \\
33.8\end{array}$ & 0.0124 & $\begin{array}{l}38.5 \\
32.3\end{array}$ & 0.0290 & $\begin{array}{l}38.4 \\
36.2\end{array}$ & 0.2358 \\
\hline Total Protein (g/l) & $\begin{array}{l}\text { Rituximab } \\
\text { Cyclophosphamide }\end{array}$ & $\begin{array}{l}65.1 \\
58.4\end{array}$ & 0.0745 & $\begin{array}{l}70.1 \\
67.9\end{array}$ & 0.4697 & $\begin{array}{l}70.7 \\
67.5\end{array}$ & 0.3330 & $\begin{array}{l}73 \\
72.1\end{array}$ & 0.6038 \\
\hline $\begin{array}{l}\text { Albuminuria } \\
(\mathrm{mg} / \mathrm{L})\end{array}$ & $\begin{array}{l}\text { Rituximab } \\
\text { Cyclophosphamide }\end{array}$ & $\begin{array}{l}35 \\
1572\end{array}$ & 0.0650 & $\begin{array}{l}22.2 \\
223\end{array}$ & 0.1638 & $\begin{array}{l}382 \\
388\end{array}$ & 0.9864 & $\begin{array}{l}26.7 \\
518\end{array}$ & 0.2090 \\
\hline $\begin{array}{l}\text { Urine creatinine } \\
(\mathrm{g} / \mathrm{L})\end{array}$ & $\begin{array}{l}\text { Rituximab } \\
\text { Cyclophosphamide }\end{array}$ & $\begin{array}{l}0.70 \\
1.04\end{array}$ & 0.0095 & $\begin{array}{l}1.18 \\
1.13\end{array}$ & 0.7359 & $\begin{array}{l}1.32 \\
1.10\end{array}$ & 0.1558 & $\begin{array}{l}1.11 \\
1.11\end{array}$ & 0.9706 \\
\hline Alb:Cr (mg/g) & $\begin{array}{l}\text { Rituximab } \\
\text { Cyclophosphamide }\end{array}$ & $\begin{array}{l}48.5 \\
1476\end{array}$ & 0.0408 & $\begin{array}{l}19.5 \\
205\end{array}$ & 0.1232 & $\begin{array}{l}262.7 \\
427\end{array}$ & 0.6030 & $\begin{array}{l}26.1 \\
533\end{array}$ & 0.2007 \\
\hline $\mathrm{C} 3(\mathrm{~g} / \mathrm{L})$ & $\begin{array}{l}\text { Rituximab } \\
\text { Cyclophosphamide }\end{array}$ & $\begin{array}{l}1.25 \\
1.39\end{array}$ & 0.1288 & - & - & - & - & - & - \\
\hline
\end{tabular}




\begin{tabular}{lllllll}
\hline $\mathrm{C} 4(\mathrm{~g} / \mathrm{L})$ & Rituximab & 0.38 & - & - & - \\
& Cyclophosphamide & 0.35 & 0.6468 & & - & - \\
& & & - & - & -
\end{tabular}

Abbreviations: WBC, white blood cells; Cr., creatinine; ALT, alanine aminotransferase; C3, complement 3; C4, complement 4.

Figure 1: Relapse-free survival during one-year follow-up comparing patients treated with rituximab and cyclophosphamide.

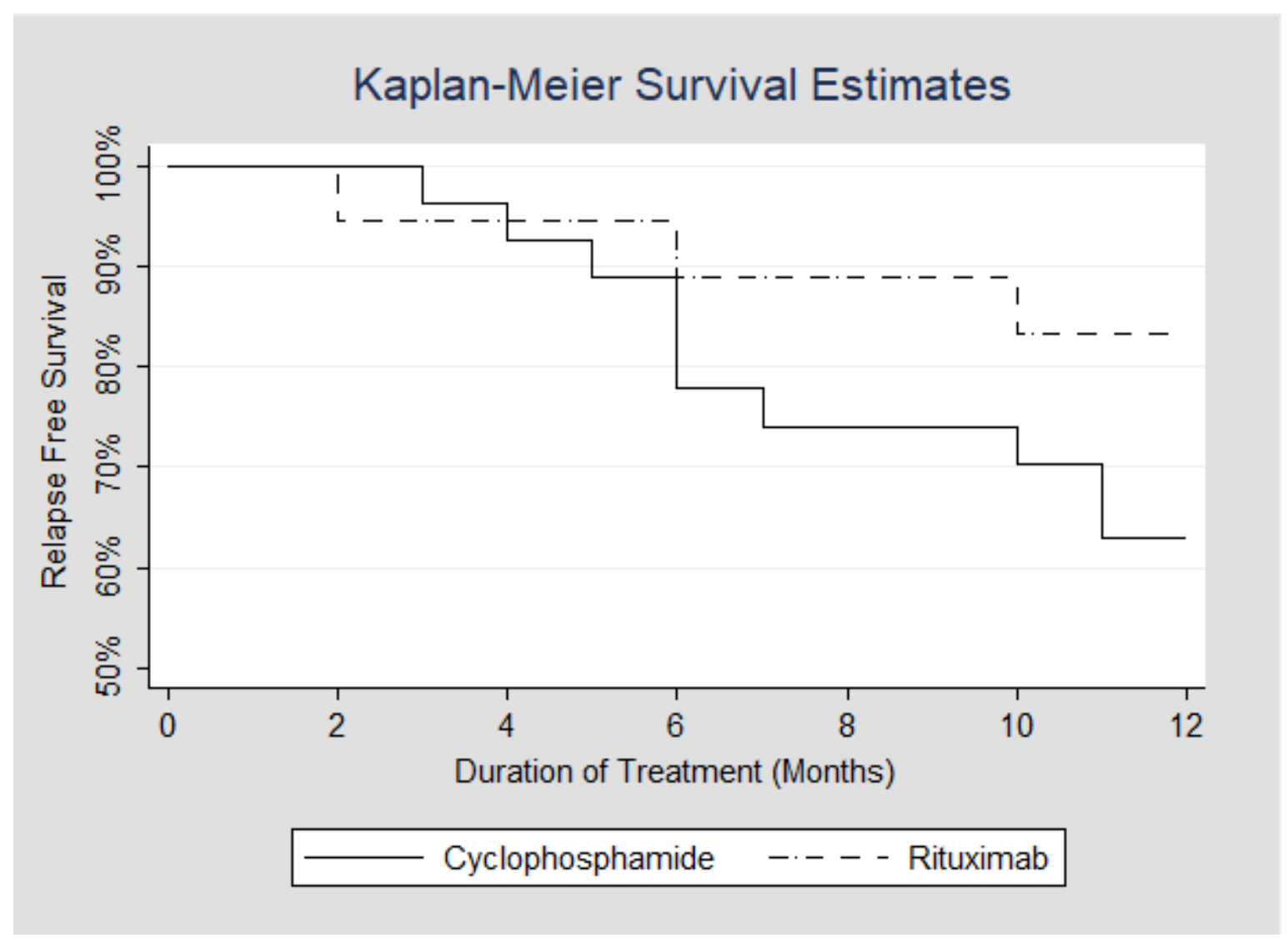


Figure 2: Steroid withdrawal within three months of treatment with rituximab and cyclophosphamide.

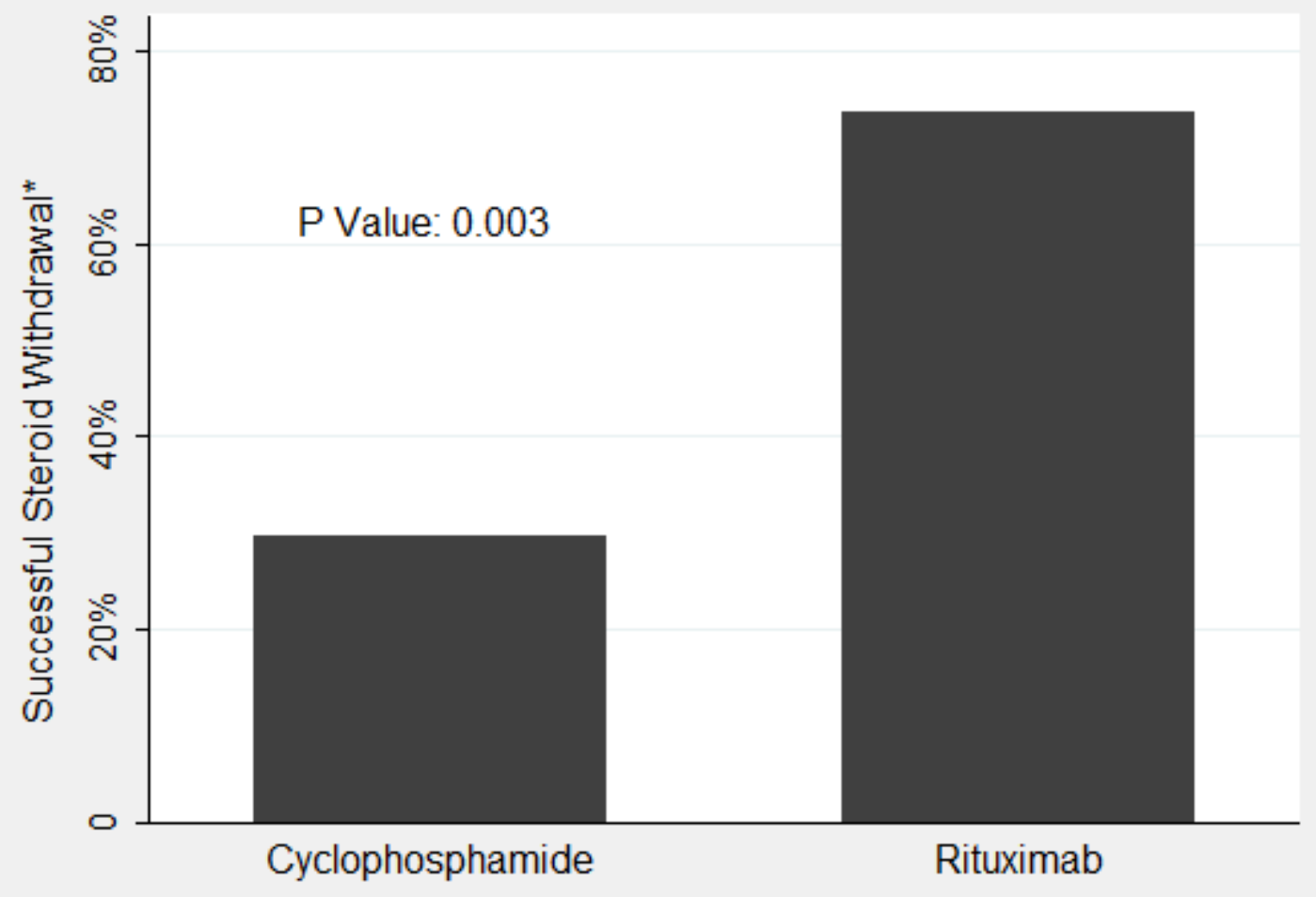

Notes: *During the initial three months of treatment. 
Figure 3: The effect of using rituximab and cyclophosphamide on reducing the steroid dose.

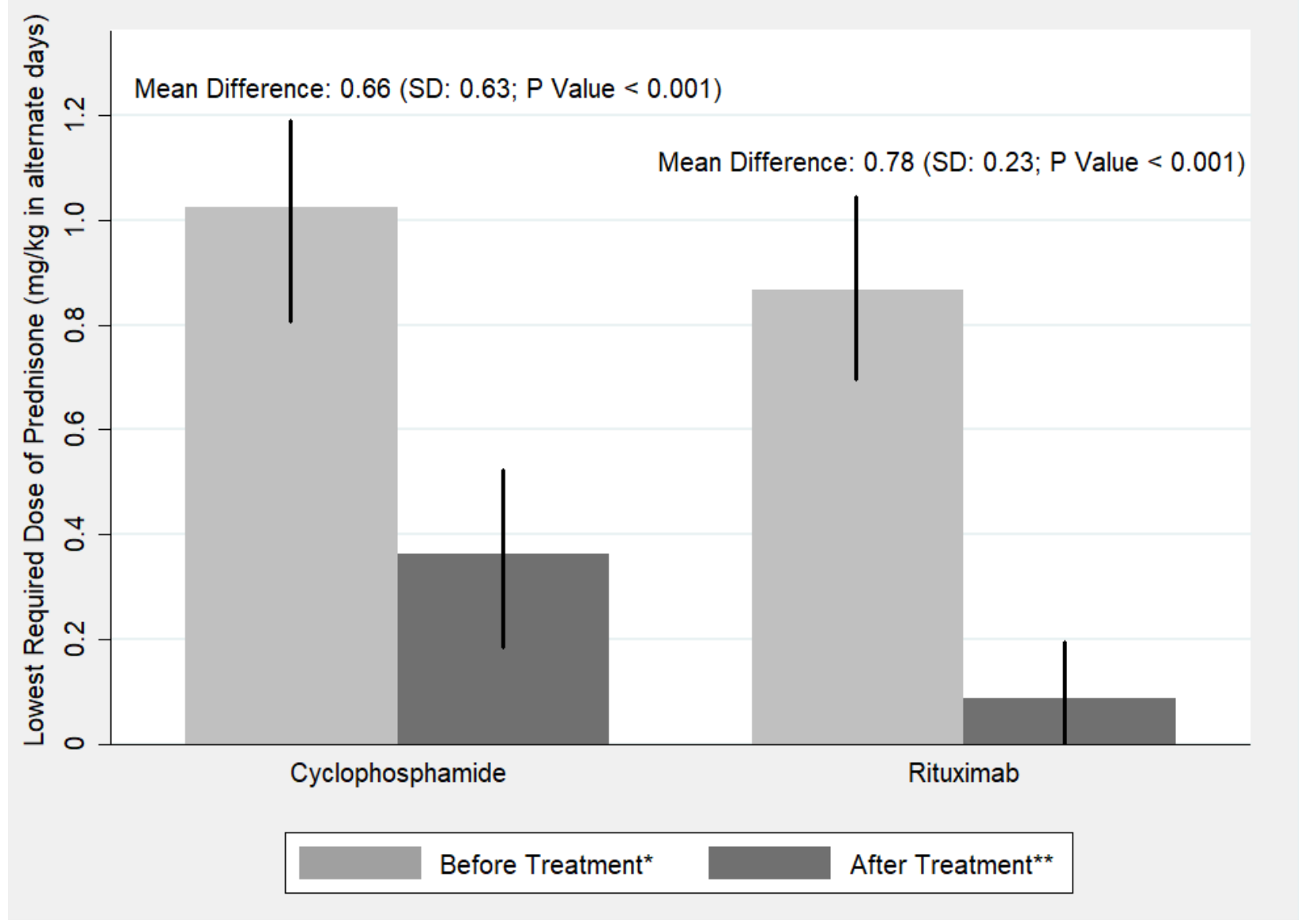

Notes: *During a year of follow-up before the start of treatment; ${ }^{* *}$ During a year of follow-up after the start of treatment. 
Figure 4: Adverse drug reactions associated with the use of rituximab compared to cyclophosphamide.

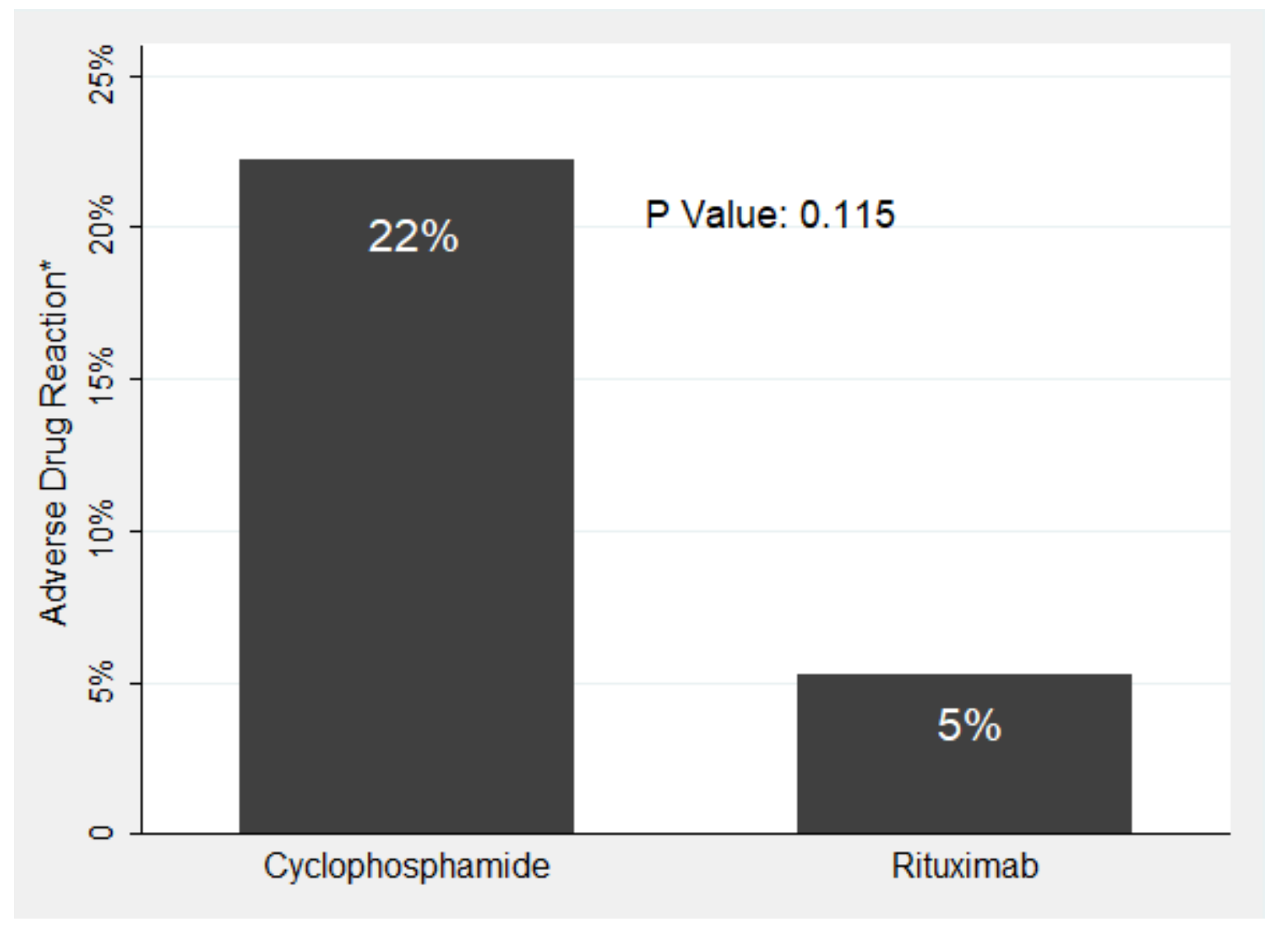

Notes: * leucopenia, acute hepatitis in cyclophosphamide group and drug reaction in Rituximab group. 
